\title{
As relações sociedade/natureza sob a perspectiva de co-evolução
}

\section{Nature/society relationships from the perspective of co-evolution}

\author{
Rosana Barroso MIRANDA*
}

\section{RESUMO}

As políticas de conservação e manejo dos recursos naturais brasileiros têm sido embasadas na correspondência estreita entre a noção de sustentabilidade ecológica regulada pelas leis do mercado e a de equilíbrio a ser restaurado e mantido no funcionamento dos ecossistemas. A vinculação entre essa noção de sustentabilidade e a de equilíbrio linear do ecossistema têm gerado a idéia de proteção total à Natureza, bem como uma lógica de manejo e conservação formulada a partir de modelos biológicos de estoques em equilíbrio e em evolução linear, geridos pelo seu rendimento máximo sustentado. Também a noção da relação ser humano/natureza tem sido concebida a partir de uma lógica única de apropriação da natureza, preconizada pelo destino inevitável da sobre-exploração dos recursos manejados de forma comunal. Coibições oriundas desse paradigma têm atingido frontalmente as populações humanas estreitamente vinculadas aos ecossistemas, gerando crescentes conflitos de uso de recursos naturais, degradação ambiental progressiva, e processos de pauperização e de exclusão social dessas populações. Com o intuito de fomentar reflexões sobre possibilidades alternativas de apropriação e de conservação dos recursos naturais, o presente ensaio visa apontar argumentos teóricos e estudos de caso que tratam a relação ser humano/natureza sob a perspectiva da co-evolução.

Palavras-Chave: co-evolução, relações sociedade-natureza, manguezais, pesca artezanal, conflitos de uso, gestão de recursos de propriedade comum, sustentabilidade.

\begin{abstract}
The conservation and management policies of Brazilian natural resources have been based on the close correspondence between the notions of ecological sustainability regulated by market laws, and of a supposed equilibrium to be recovered and maintained in the functioning of the ecosystems. The connection between this notion of sustainability and the linear balance of the ecosystem has generated the idea of
\end{abstract}


total protection of nature, as well as a rationale of management and conservation formulated from biological models of stocks in equilibrium and in linear evolution, managed for their maximum sustained yield. Also, the notion of human/nature relationships stems from an exclusive logic of appropriation of nature, preconized by the inevitable destiny of overexploitation of resources managed in a communal way. Restraints issued from that paradigm have straightforwardly affected human populations closely linked to ecosystems, generating growing conflicts over natural resources use, environmental degradation, impoverishment processes and social exclusion of those populations. Aiming to provoke reflections about alternative possibilities of natural resources appropriation, the present essay presents theoretical arguments and case studies to approach human/nature relationships from the perspective of co-evolution. Key-words: co-evolution, nature/society interactions, small-scale fisheries, mangroves, use conflicts, common property resources, sustainability.

\section{Introdução}

O sistema de pensamento que rege a atual condução das políticas públicas de conservação da natureza no Brasil apresenta uma forte perspectiva preservacionista na gestão dos ecossistemas, a partir da construção do neomito da Natureza intocada. Essa idéia de wilderness ${ }^{1}$ gera a noção da natureza como um mundo selvagem, que existiria em estado "puro", anterior ao aparecimento do ser humano. E supõe a incompatibilidade entre as ações de quaisquer grupos humanos e a conservação dos recursos. Assim, áreas naturais necessitam de uma "proteção total" desse destruidor do mundo natural, o ser humano (DIEGUES, 2001).

Como apontam Raynaut, Zanoni e Lana (2002), essa idéia de proteção total materializada nas diretivas legais e constitucionais sobre os ambientes gera crescentes conflitos de uso de recursos naturais, degradação ambiental progressiva, e processos de pauperização e de exclusão social das populações locais e tradicionais, principalmente aquelas residentes em Unidades de Conservação de uso indireto. Essas problemáticas têm sido acionadas tanto pela lógica preservacionista extrema quanto pelo pensamento neoliberal, que acabam por efetivar o oposto à equidade e justiça social e à conservação efetiva dos recursos naturais.

No que diz respeito à política de manejo de recursos, a noção hegemônica de sustentabilidade é concebida como a sustentabilidade ecológica regulada pelas leis do mercado e utiliza a formulação de modelos biológicos para representar a evolução de um determinado recurso em equilíbrio, em que a exploração é considerada em progressão linear, baseada no rendimento máximo sustentado, e fundada numa representação da $\mathrm{Na}$ tureza a partir da noção de estoques ou mananciais ${ }^{2}$ a serem geridos (WEBER, 1997). A sustentabilidade de exploração de determinado recurso, nessa perspectiva, é dada pelo nível de esforço de captura que venha a conferir em longo prazo as mais altas capturas estáveis (SPARRE; VENEMA, 1997).

Em que pese a validade indiscutível dos conhecimentos da Biologia de Populações, e da Biologia da Conservação, de fundamental importância para o manejo da base de recursos, bem como a necessidade de mecanismos de regulação de uso e de conservação dos recursos naturais, é importante ressaltar dois aspectos a serem reconsiderados nas atuais formas de ação de manejo e conservação da Natureza

O primeiro aspecto diz respeito à própria noção de natureza no que se refere à idéia de correspondência estreita entre a noção de sustentabilidade e a de equilíbrio a ser restaurado e mantido no funcionamento dos ecossistemas. Essa vinculação entre sustentabilidade e equilíbrio do ecossistema necessita ser revista, a partir de uma análise crítica de cunho teórico de conceitos ecológicos como os de equilíbrio, de estabilidade, de evolução, bem como de adaptação e ajustamento dos sistemas biológicos ${ }^{3}$. Estas teorias ecológicas exercem influência para além de seu saber disciplinar, em

1 Nascida do movimento preservacionista norte-americano dos anos 50.

2 Entende-se por manancial (no inglês stock) um subconjunto de uma espécie que possui os mesmos parâmetros de crescimento e mortalidade, e que habita uma área geográfica particular (SPARRE; VENEMA, 1997).

3 Segundo von Bertalanffy e Bogdanov (apud CAPRA, 1997), os sistemas vivos são sistemas abertos que operam afastados do equilíbrio. Seus processos organizacionais, por sua vez, apresentam duas vias básicas, formação/conformação e regulação (PROSSER, 1958), e possuem como característica termodinâmica a capacidade de criar e manter um elevado grau de ordem interior, em uma condição de baixa entropia (ODUM, 1988). 
interlocução com outras áreas do conhecimento, no que diz respeito aos fundamentos da noção de sustentabilidade ecológica e sua relação com as problemáticas socioambientais.

O segundo aspecto refere-se à noção da relação ser humano/natureza, e a idéia estanque de pensar apropriação da Natureza a partir de uma lógica única. ${ }^{4}$ Essa idéia desconsidera as diversas lógicas de apropriação social dos recursos, sob a perspectiva da sociodiversidade, posto que diferentes modalidades de apropriação interferem na condição de conservação dos recursos, e na possibilidade de sucesso de distintas condutas de regulação de seus usos.

Essas noções de natureza e da relação ser humano/natureza têm estado envoltas em um debate teórico e político marcado pela dicotomia de pensamento entre biocentristas e antropocentristas, bem como entre concepções preservacionistas, conservacionistas e desenvolvimentistas.

Construídas no cerne do racionalismo cartesiano logocêntrico e das idéias mecanicistas advindas dos evolucionistas-neo-darwinistas, ${ }^{5}$ entretanto, essas duas noções têm passado por importantes transformações que tendem a romper com a visão preditiva e linear de natureza em equilíbrio e a visão dualista da relação sociedade/natureza, visões essas características da cultura e da ciência ocidentais.

Essas transformações advêm principalmente das contribuições da perspectiva sistêmica dos fenogeneticistas, ${ }^{6}$ bem como da construção de saberes ambientais baseados na valorização da sociodiversidade e do reconhecimento de processos de co-evolução $S o$ ciedade/natureza. ${ }^{7}$

Com o intuito de colaborar com as necessárias reflexões sobre alternativas de manejo dos recursos natu- rais, esse ensaio pretende apontar alguns argumentos teóricos e estudos de caso que repensam a relação ser humano/natureza, sob a perspectiva da co-evolução.

Entretanto, é necessário já esclarecer aqui que essas reflexões sobre a necessidade de se incorporar diferentes lógicas de apropriação e de manejo de recursos naturais, não estão defendendo o uso total e indiscriminado dos recursos, nem mesmo a extinção de medidas de conservação. Tampouco se alega aqui que todas as comunidades tradicionais têm sempre e necessariamente uma relação harmoniosa e conservativa em relação aos seus recursos. Outra questão pertinente é que, ao contestar algumas perspectivas de análise relacionadas à idéia de evolução ou de equilíbrio, não se está aqui refutando a teoria da evolução no pensamento original de Darwin, tampouco refutando o conceito de homeostasia, ou de equilíbrio dos ecossistemas. Esse ensaio pretende sim é trazer reflexões teóricas que incorporam por superação determinados conceitos utilizados no estudo das relações sociedade(s)/natureza(s), a fim de que se possa aprimorar instrumentos de análise teórica e prática na gestão, conservação e manejo dos recursos naturais, considerando o dinamismo e a diversidade socioambiental.

\section{A natureza e seu suposto equilíbrio}

A noção de natureza em equilíbrio está embasada no principio da constância, da restauração e da manutenção de características estanques de determinado sistema biológico. Essa noção é construída a partir das idéias de Claude Bernard e de Walter Cannon, que definem o conceito de homeostase como "o mecanismo auto-regulador que permite aos organismos manter-se num es-

4 A obra A tragédia dos comuns, de Hardin (1968), previa o destino inevitável da sobre-exploração dos recursos manejados de forma comunal, concluindo que a liberdade em relação ao uso e apropriação de recursos comuns gera a ruína de todos (apud FEENY et al., 2001), idéia essa que incorporou-se nos estudos convencionais sobre planejamento ambiental e uso de recursos (McEVAN, 1988), influenciando as concepções de Natureza contidas no direito ambiental.

5 O Darwinismo Social é uma corrente de pensamento que incorpora e reinterpreta as idéias de Darwin (1859) sobre a evolução biológica das espécies, a partir de relações de competiçāo e da seleção natural do mais forte, projetando-as para questões políticas. Estas concepções aparecem no cenário científico, já no século XVIII, por meio do determinismo biológico e do racismo científico. No século XIX, as idéias darwinistas foram utilizadas para fundamentar o projeto da sociedade ocidental industrial, pelas concepções de progresso e pela abolição do catastrofismo. Esse Darwinismo Social, agregando-se aos conhecimentos da biologia molecular, gera o chamado neodarwinismo, propondo como base explicativa da evolução as mutações aleatórias dos genes (THOMPSON, 1990; JAPIASSÚ, 1996). 6 O Fenogeneticismo propõe uma contracorrente do pensamento neodarwinista, atribuindo um papel importante para o fenótipo no processo evolutivo, por considerar que o meio ambiente é modificado e construído por seus organismos habitantes (LEWONTIN, 1983, apud FOLADORI, 1999).

7 Destacam-se as contribuições de Moscovici; dos fundamentos da Etnociência, e da Etnoconservação; bem como da concepção de resiliência de Holling (1973) e co-evolução dos sistemas socioambientais, na perspectiva fenogeneticista, e a noção de que a Natureza é uma representação social, um construto social, com dimensões imaginárias (contribuição de análise simbólico-subjetiva da Antropologia Neomarxista de GODELIER, 1984). 
tado de equilíbrio dinâmico, com suas variáveis flutuando entre limites de tolerância" (CANNON, 1932 apud CAPRA, 1997).

Odum (1988), por sua vez, define a homeostasia do Ecossistema com o seguinte enunciado:

"Os ecossistemas, tal como as populações e seus organismos componentes, são capazes de auto-manutenção e de auto-regulação."

O termo homeostasia traduz assim a tendência que os sistemas biológicos têm para resistir à alteração e permanecer em estado de equilíbrio.

Esse conceito de equilíbrio, construído teoricamente nos idos anos 30, é ainda hoje fortemente interpretado como uma noção de permanência, a qual, por sua vez, traz a idéia de uma constância de ajustamentos preditivos, na concepção do eterno retorno dos fenômenos naturais e de um progresso linear e ininterrupto dos organismos e dos ecossistemas, sem a intervenção humana. Adverte-se ainda que essa concepção de evolução e de desenvolvimento linear e ininterrupto dos fenômenos biológicos, recebe a influência da perspectiva evolucionista de Darwin, quanto à noção de progresso linear e anticatastrofista, e de um produto final do processo evolutivo. Isso está bem expresso na definição do conceito de comunidade clímax ${ }^{8}$ e do desenvolvimento dos ecossistemas, ${ }^{9}$ enunciados por Odum (1988).

Entretanto, apesar desse conceito de equilíbrio estável e preditivo e de um eterno retorno dos fenômenos naturais estarem ainda presentes e pulsantes nas ações e diretivas das políticas ambientais atuais, estes tem sido incorporados por superação teórica, tanto no âmbito da fisiologia, quanto da ecologia, desde a década de 70 .

No âmbito da fisiologia a idéia de equilíbrio estável expressa no conceito de homeostasia, é incorporada por superação por duas pesquisadoras, Magnum; Towle (1977), as quais propõem o conceito de enantiostasia para o entendimento das estratégias responsivas de caráter bioquímico e fisiológico em organismos invertebrados, a fim de evidenciar as dinâmicas dos ajustamentos entre diferentes parâmetros fisiológicos a estímulos ambientais. Esse conceito de enantiostasia in- corpora a idéia de desequilíbrio, visto que respostas de regulação ou de conformação dos invertebrados marinhos, por exemplo, ocorrem muitas vezes na manutenção de determinado parâmetro fisiológico a partir da alteração de um ou vários outros parâmetros correlacionados.

A noção de desequilíbrio como uma maneira de ajustamento é de tal interesse que aponta uma nova percepção das dinâmicas adaptativas fenotípicas. Assim, quando se observa um ajustamento sob a perspectiva convencional da homeostasia, o enfoque está no ajustamento de um parâmetro do sistema, enquanto que na perspectiva da enantiostasia o que está sob observação é o todo dinâmico das respostas compensatórias necessárias para que o sistema possa chegar a um novo ajuste.

Esse novo ajuste de funcionamento do sistema, por sua vez, nunca será igual ao anterior. Existe uma memória bioquímica e fisiológica dessa dinâmica de ajustamento organísmico (como profundamente estudado, entre outros, por HOCHACHKA; SOMERO, 1984), aquilo que em fisiologia pode ser conceituado como aclimatação (em condições ambientais laboratoriais) ou aclimatização (em condições do ambiente natural) (MIRANDA, 1994).

Nessa perspectiva, os sistemas biológicos tendem sim a buscar equilíbrios, mas esses ajustes passam por dinâmicas complexas, atuando em conjunto com desequilíbrios compensatórios, e transformam o próprio sistema nesse processo. Não há o eterno retorno, mas sim, ajustamentos complexos e ininterruptos para a conservação do sistema.

Assim como tem ocorrido nos estudos de fisiologia, a superação da idéia de equilíbrio estável e de um eterno retorno ao estado estacionário também tem ocorrido no estudo dos ecossistemas. Nesse último caso, a superação dessa idéia aponta para a construção de um novo conceito, elaborado por Holling sob a denominação de resiliência ecológica.

Resiliência ecológica para Holling (1973) “é a quantidade de perturbação que o sistema pode absorver antes de transformar-se em um domínio de estabilidade

\footnotetext{
8 Comunidade climax é a comunidade final, ou estável, em um desenvolvimento seriado; essa comunidade se perpetua a si mesma e está em equilíbrio (optimum) com o hábitat físico (ODUM, 1972).

9 O conceito de comunidade clímax conduz à idéia de evolução dos ecossistemas sob a perspectiva de um desenvolvimento seriado, em que um ambiente menos diversificado e menos complexo pode ser encarado como um momento histórico primitivo do ecossistema mais complexo, ou clímax. Esses conceitos, por sua vez, têm sido amplamente aplicados na análise de sustentabilidade dos ecossistemas.
} 
alternativa" (apud GUNDERSON, 2001). Essa concepção de capacidade de absorção de perturbações, de desequilíbrios incorpora a noção de busca de equilíbrio do conceito de homeostasia, mas a supera em relação à idéia de estática, de uma estabilidade ecológica tida como uma habilidade do ecossistema retornar eternamente a um estado de equilíbrio após uma perturbação, presente no conceito de Comunidade clímax, e no equilíbrio ótimo (optimum).

Além disso, no conceito de Holling, quando uma perturbação é suficientemente forte para empurrar um sistema biológico para além de seus limites de resiliência, ele pode se extinguir localmente e ser substituído por um novo sistema, que assume distinta configuração naquele mesmo espaço.

Assim, Holling constrói o conceito de resiliência ecológica, incorporando o conceito de homeostasia, por superação de sua visão estática anterior. O equilíbrio e a estabilidade não deixam de ser conceitos válidos, mas são vistos como um todo dinâmico, reconhecendo os fenômenos de ajustamento a partir de uma perspectiva de maior complexidade.

Nesse sentido pode-se pensar em múltiplos pontos de estabilidade possíveis para os sistemas biológicos em uma determinada área. Ou seja, múltiplos pontos de equilíbrios alternativos, em diferentes escalas de tempo e de espaço.

Então, se vários pontos de estabilidade são possíveis, é importante perceber a história dos ajustamentos dos sistemas biológicos, bem como as suas configurações, enquanto respostas a perturbações das mais diversas naturezas (RAYNOUT, ZANONI; LANA, 2002). Sugere-se aqui, que a análise do tipo de resposta apresentada pelo ecossistema para determinada perturbação, seja biótica ou abiótica, antrópica ou não, poderá ser realizada dentro da perspectiva de respostas conformadoras, reguladoras ou deformadoras no sistema, como caracteriza Prosser (1958), referindo-se aos sistemas biológicos em geral.

Portanto, a dinâmica histórica das configurações dos ecossistemas é condicionada tanto por eventos preditivos como não-preditivos e pode estar relacionada a fenômenos interativos das mais diversas naturezas.

Essa perspectiva de interatividade de ajustamentos é outra grande contribuição teórica para o entendimento de processos de ajustamentos dos sistemas bio- lógicos. Uma de suas expressões mais fundamentais é a co-evolução biológica, conceito elaborado por Ehrlich; Raven (1965 apud ODUM, 1988), a partir de seus estudos sobre as interações bioquímicas entre borboletas e plantas. Em suas análises, esses autores apontam que não só a diversidade de plantas pode tender a aumentar a diversidade de insetos fitófagos, mas também o inverso pode ser verdadeiro. A planta e o herbívoro evoluem conjuntamente no sentido de que a evolução de cada um é interdependente da evolução do outro. Assim

co-evolução é um tipo de evolução da comunidade (interações evolutivas entre organismos nos quais é mínima ou nula a troca de informação genética entre os diversos tipos) envolvendo interação seletiva recíproca entre dois grupos principais de organismos com uma relação ecológica estreita, com exemplo, plantas e herbívoros, organismos grandes e os respectivos microorganismos simbiontes, ou parasitas e seus hospedeiros.

Nessa perspectiva, as seleções recíprocas graduais podem contribuir para o curso da evolução da diversidade, interdependência e homeostasia ao nível da comunidade (ODUM, 1988).

Da mesma maneira, os estudos de Lewontin (1983) e Margulis (1990) apontam para a capacidade que os organismos têm de modificar seu meio ambiente. Assim, os organismos e seus fenótipos têm um papel importante ao promover o processo evolutivo tanto das espécies em si, quanto dos seus respectivos ambientes, considerando que o meio ambiente é modificado e construído por seus organismos habitantes, nas relações organismo-ambiente, estabelecidas no nicho ecológico, conforme advoga o pensamento do fenogeneticismo.

\section{A relação sociedade/natureza e a perspectiva de co-evolução}

O conceito de co-evolução se estabelece primeiramente em ecologia, mas se difunde para as questões socioambientais, estando presente já no pensamento de Moscovici (1974 apud DIEGUES, 1998). Esse autor aponta três idéias principais, fundamentais para a análise da relação ser humano/natureza. 
Primeiro, que o ser humano produz o meio que o cerca e é ao mesmo tempo seu produto, assim sendo, ele é uma das forças da Natureza, e é de seu interesse estreitar as ligações entre as forças naturais, permitindo que estas se desenvolvam, se renovem, ao invés de esgotálas na busca sem fim da exploração que causa destruição, que transforma abundância em escassez.

Nessa visão, a interferência humana é normal e natural ao curso dos fenômenos e ciclos naturais. O problema reside não no fato, mas na maneira como o homem intervém na natureza.

Segundo, que a natureza faz parte da nossa história, então não é a busca do paraíso perdido, mas o reconhecimento de que a natureza é sempre histórica e a história tem relação direta com o natural. O problema está em compreender a relação entre a história e a condição da natureza em cada momento vivido.

Terceiro, que é a coletividade e não o indivíduo quem se relaciona com a natureza. A sociedade pertence à Natureza, consequientemente é produto do mundo natural por um trabalho de intervenção constante. Essa última premissa, entretanto, necessita evitar recair no determinismo biológico, sob o perigo de colocar mais uma vez a sociedade como um subsistema ecológico.

Esses apontamentos de Moscovici abrem portas para entender que a natureza não é uma realidade plácida, uniforme, em perfeito equilíbrio. Ao contrário, ela é diversidade, criação constante de diversidades, existência complementar de cada força e de cada espécie. Sua regra é a heterogeneidade, e a evolução se faz sob esse signo (DIEGUES, 1998).

Ao reconhecermos as dinâmicas ambientais como complexas e heterogêneas, e ao observarmos o potencial de interação e de interdependência constante das diferentes populações humanas com seus ecossistemas percebe-se, como advoga Diegues (1998) a importância de conhecermos melhor cada cultura, de cada região e de cada coletividade, onde cada trabalho, linguagem, costumes, técnicas, ciências, saberes se intercambiam, ao invés de se impor ou sobrepor.

Essa noção de ajustamentos socioculturais aos condicionantes ecossistêmicos também aparece nas idéias da Ecologia Cultural, as quais rompem com o determinismo ambiental ${ }^{10}$ e também com o possibilismo histórico, ${ }^{11}$ ao estudar os processos adaptativos por meio dos quais as sociedades são afetadas pelos ajustes básicos de certos aspectos da cultura, como aqueles relacionados às atividades de subsistência, de tecnologia, bem como de organização social. Desta maneira, estratégias de produção, troca, comercialização, entre outras, são estratégias adaptativas aos condicionantes ambientais (DIEGUES, 1998).

Além desse elenco de ajustamentos de cunho mais prático, outros elementos da cultura, como as formas de representações simbólicas, são também imprescindíveis no estudo dos processos relacionais entre ser humano e Natureza. Para Godelier (1984), adaptar-se não significa submeter-se às imposições naturais, mas tomá-las em consideração, à luz de uma compreensão simbólico-subjetiva, ampliando seus efeitos positivos ou atenuando os negativos.

\section{Processos adaptativos entre comunidades hu- manas e ecossistemas}

Existem fortes indícios de processos adaptativos co-evolucionários entre ecossistemas e culturas, presentes, principalmente, em sociedades com estreitos vínculos históricos com o ambiente. Essas sociedades são denominadas por Dassmann (1988 apud: DIEGUES; ARRUDA, 2001) como povos dos ecossistemas, e são identificadas por suas culturas tradicionais, mantendo interdependência estreita com o ambiente, cujas estruturas sociais estão profundamente vinculadas às dinâmicas naturais, associadas à pequena produção mercantil (DIEGUES, 1993 apud: DIEGUES; ARRUDA, 2001) e ao uso de tecnologias de baixo impacto.

Diversas dessas comunidades que dependem diretamente dos recursos, mantêm determinadas ações conservativas dos recursos explorados, ações essas moduladas por relações socioculturais e econômicas, vinculadas inclusive aos saberes ecológicos comunais, indicando que as biodiversidades e as sociodiversidades co-evoluem e co-adaptam-se. Há inúmeros casos relatados em trabalhos como os de Mccay e Acheson (1987),

10 Pensamento baseado em Ratzel, que entende a cultura como determinação do meio ambiente (DIEGUES, 1998).

11 Pensamento que entende a origem dos padrões culturais como independente do Meio Ambiente (DIEGUES, 1998). 
Berkes (1989), (1999), Diegues (1998), Cunha e Rougelle (1989), Begossi (2001), Seixas (2002), entre outros, que indicam que a apropriação dos territórios e dos recursos naturais, em diferentes sociedades rurais com estrutura comunal, apresenta dinâmicas complexas, condicionadas tanto por eventos ecossistêmicos e abióticos, quanto por fenômenos socioculturais e econômicos, sejam eles preditivos ou não.

Além disso, Peck e Feldman (1986 apud BERKES, 1989) e Berkes (1989), alegam serem os mecanismos de cooperação como de vital importância para processos co-evolucionários na perspectiva da ecologia humana, os quais, até então, passaram subestimados nas lógicas de Darwin e Adam Smith. Essas relações de cooperação já foram amplamente reconhecidas em diversos estudos de Ecologia Animal, sob o foco da predação prudente e dão base aos fundamentos da Teoria da Cooperação.

Esses processos de cooperação apresentam-se em três possíveis mecanismos, sejam eles, seleção por família ou parentesco, seleção de grupo, e reciprocidade. Esses três mecanismos, por sua vez, atuam em sincronia, quando as populações humanas vivem em um determinado território, com laços de parentesco, e são identificáveis por uma análise temporal, de historicidade, espacial, de territorialidade.

Um exemplo dessa dinâmica é evidenciada em estudos desses autores sobre as relações territoriais de grupos caçadores do Canadá, em James Bay, que se ajustam aos ciclos de padrões de uso e abundância de recursos.

Nesse caso, quando os recursos são oferecidos com uma abundância tal que venha a suprir as necessidades do grupo, as relações territoriais são mínimas, e os recursos são apropriados em sistema de livre acesso. Em outro período histórico, em situação de determinada escassez, algumas relações de território passam a determinar regulação de acesso por determinados grupos e a porções de território, fenômeno esse que se apresenta como uma relativa diminuição do sistema de propriedade comunal sem, entretanto, recair no extremo oposto da relação de privatização estrita. Quando os caçadores, passam por uma escassez ainda maior, a regulação de território se intensifica, passando para a regulação de acesso, diretamente aos grupos familiares.

Essa dinâmica está expressa no diagrama apresentado na seqüência:

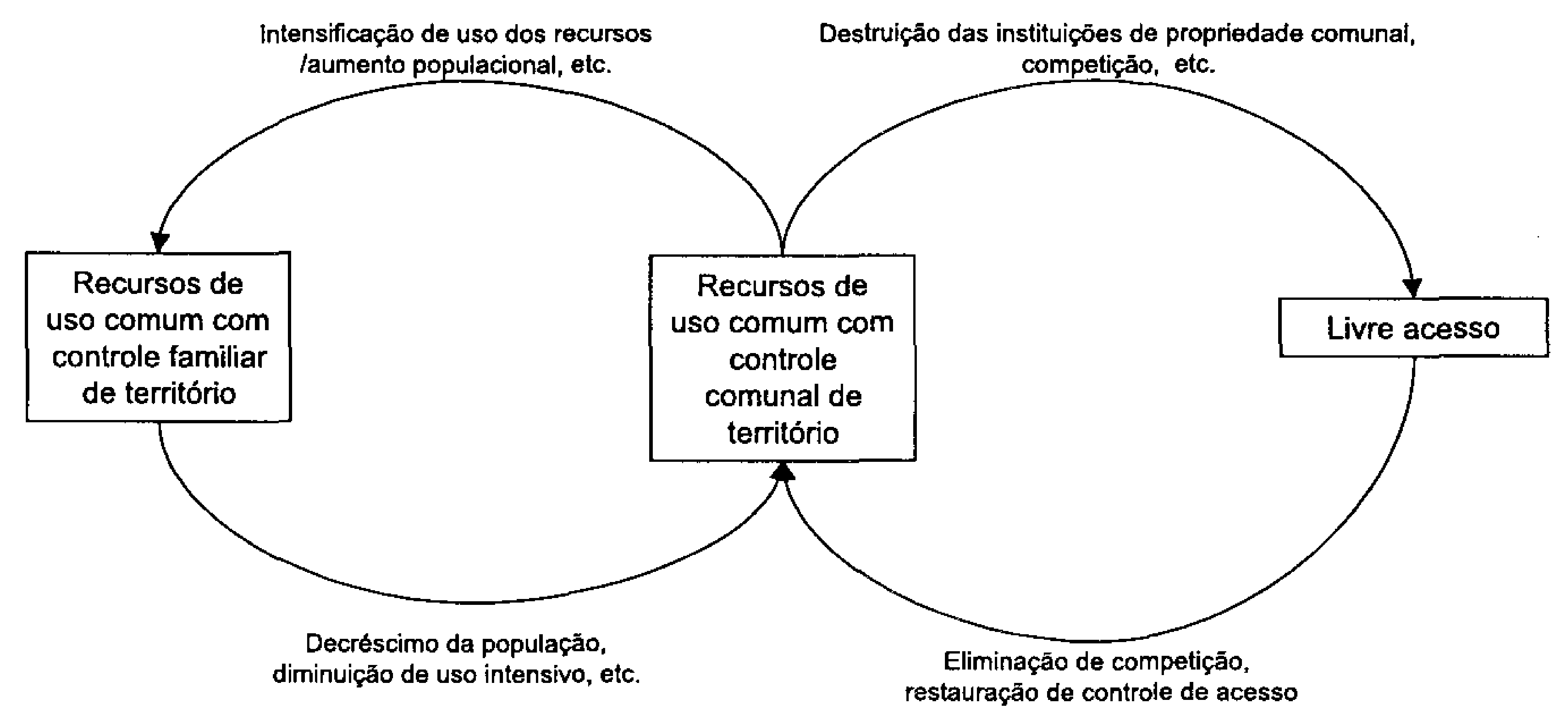

Fonte: adaptado de Berkes, 1989 
Como apontado neste estudo de caso de Berkes (1989), a territorialidade tem sido considerada como um mecanismo de auto-regulação comportamental, e é evidenciada não só entre grupos humanos, mas também em diversas populações de muitos mamíferos caçadores.

Então, assim como esses grupos humanos modificam suas regras de acesso ao longo do tempo, em resposta à escassez diferencial dos recursos, também os mananciais desses recursos podem responder positivamente às diferentes regulações das práticas de exploração. ${ }^{12}$ Portanto, o estabelecimento de regras de conduta ajustado às maneiras de uso e aos territórios de acesso, sejam eles exclusivos ou não, para distintos grupos, necessita de conhecimentos sobre as dinâmicas naturais, em seus ritmos sazonais, circadianos, ou mesmo não preditivos, tanto quanto das heterogeneidades espaçotemporais dos ecossistemas e de seus recursos de interesse específico. Assim sendo, o conhecimento ecológico tradicional é chave-mestra de articulação dos mecanismos de ajustes nas apropriações comunais.

Entende-se aqui que o conhecimento ecológico tradicional é um

complexo integrado de conhecimentos-práticas-crenças, que envolve processos adaptativos e é perpetuado através de gerações por transmissão cultural sobre as relações dos seres viventes (incluindo os humanos) entre si e com o ambiente (BERKES, 1999).

Esse conhecimento organiza-se em quatro dimensões, quais sejam, primeiro nível, de conhecimento sobre aspectos ecológicos estritos dos recursos, segundo nivel, sobre os sistemas de manejo de recursos, terceiro nível, sobre as instituições sociais que os regulam, e quarto nível, sobre visão de mundo, e pensamento paradigmático (BERKES, 1993; GADGIL et al., 1995 apud BERKES, 1999).
Desta maneira,

o conhecimento tradicional é tanto cumulativo quanto dinâmico, construído pela experiência e adaptado às mudanças, e é um atributo de sociedades com continuidade histórica no uso de recursos de um ambiente particular (BERKES, 1999).

Nessa perspectiva, o saber local não deve ser encarado apenas de uma maneira pontual, descritiva, mas sim, de forma articulada e funcional, compreendendo suas inter-relações com as dinâmicas de usos, suas modalidades de acesso e de controle e transferência de direitos de acesso, bem como de repartição ou partilha dos recursos.

Assim, o conhecimento, os saberes e os costumes nas culturas tradicionais estão entrelaçados em cosmovisões, formações simbólicas e sistemas taxonômicos através dos quais a natureza é classificada, e os usos dos recursos ordenados. A Cultura atribui nestas circunstâncias valores-significado à Natureza, por meio de suas formas de cognição, de seus modos de nominação e de suas estratégias de apropriação dos recursos.

\section{O caso das comunidades pesqueiras artesanais e dos manguezais paranaenses}

Um estudo de caso que também aponta para determinadas dinâmicas de apropriação dos recursos naturais, condicionadas aos saberes comunais e aos ajustamentos territoriais, diz respeito aos modos de apropriação dos extrativistas de manguezais no Complexo Estuarino da Baía de Paranaguá, no Paraná (MIRANDA, em preparação).

Nesse Complexo Estuarino, os recursos bênticos de manguezais têm sido explorados por comunidades de pescadores artesanais, ${ }^{13}$ cuja atual atividade de pesca é

12 Entretanto, nem sempre essa relação é direta e linear. As dinâmicas de resposta dos ecossistemas aos diferentes tipos de perturbação são assunto complexo, envolvem uma análise pormenorizada das respostas diferenciais de cada nível do sistema (desđe organismo, população e comunidade até o ecossistema como um todo), considerando a intensidade dessa resposta - fenotípica ou genética -, sua qualidade ou tipo (se reguladora, conformadora ou deformadora do sistema) e as escalas temporais e espaciais desses fenômenos.

13 Atualmente, grupos oriundos de outros setores produtivos têm também explorado esses recursos, a exemplo dos desempregados da estiva e de grupos contratados por empresários, vinđos muitas vezes de outros estados (principalmente São Paulo, Rio de Janeiro e Santa Catarina), os quais realizam empreitadas na coleta principalmente de caranguejos e ostras. Entretanto, o maior contingente extrativista desses recursos ainda advém das comunidades de pescadores artesanais paranaenses. 
produto de um movimento histórico da pesca combinada a outras atividades.Esse estudo de caso valeu-se de diversas metodologias, como a elaboração de diagnósticos gerais sobre as dinâmicas de apropriação dos recursos de manguezais, histórias de vida dos pescadores artesanais, saberes comunais e mapas cognitivos sobre as heterogeneidades dos bosques e da distribuição dos recursos da fauna nos manguezais, estudos ecológicos de campo sobre a fisiografia de determinados locais no Complexo Estuarino, e sobre a distribuição e abundância dos três recursos da fauna apontados como importantes economicamente, a saber, Ucides cordatus (o caranguejo-uçá), Crassostrea rhizophorae (a ostrado-mague) e Mytella guyanensis (o sururú). Essa pesquisa organizou-se em duas grandes etapas: $1^{\circ}$. Diagnóstico geral dos modos de apropriação dos manguezais de todo o Complexo Estuarino, e $2^{\circ}$. Estudos de caso, nas comunidades de Amparo (Estuário da Baía de Paranaguá) e Poruquara (Baía dos Pinheiros), considerando os saberes comunais e modos de apropriação dos bosques locais, bem como estudos ecológicos sobre a fisiografia local e a abundância dos recursos faunísticos de interesse neste estudo.

Embora o trabalho ainda esteja em andamento, alguns resultados já permitem ilustrar alguns saberes comunais articulados aos modos de apropriação, que exemplificam alguns ajustamentos adaptativos às condições socioambientais. Foram realizadas 53 entrevistas abertas com pescadores artesanais e comerciantes de pescado, entre dezembro de 2002 e agosto de 2003. Essa pesquisa abrangeu os distintos setores do Complexo da Baía de Paranaguá, compondo um universo de 31 localidades, dentre elas, 29 vilas pesqueiras, o balneário de Pontal do Sul, e o mercadinho das ostras de Paranaguá.

As entrevistas, individuais e coletivas, ocorreram tanto em terra, em visita às residências e outros estabelecimentos das vilas, quanto nas embarcações, durante atividades pesqueiras, e outras, realizadas no mercado público de pescados de Paranaguá. As entrevistas foram sua maioria, registradas em gravador, com a devida autorização dos entrevistados. Após sua realização, aquelas registradas foram transcritas em totalidade, respeitando a estrutura linguística do discurso dos entrevista- dos, e posteriormente as informações específicas foram tratadas taxonômicamente.

Para compreender a relação histórica desses pescadores com o ambiente como um todo e com os manguezais, em primeiro lugar, far-se-á uma incursão na literatura, ilustrando-a com histórias de vida coletadas durante o estudo (veja-se também o trabalho de Andriguetto Filho, neste volume).

\section{Uma breve história dos pescadores artesanais paranaenses}

Ao longo dos anos, esses grupos humanos passaram de uma atividade de subsistência, para a pequena produção de pescadores-lavradores, e finalmente para a atual condição exclusiva de pescadores artesanais (DIEGUES, 1983; CUNHA; ROUGELLE, 1989). Seguem relatos de histórias de vida de idosos da Comunidade de Amparo:

Minha mãe trabalhava na roça, trabalhava na roça, era pescador e trabalhava na roça, é por isso que comida não faltava, meu pai trabalhava na roça, meu pai era pescador, minha mãe, trabalhando em lavoura...

O pessoal aqui plantava muito, aqui era o arroz, era a banana...Agora nem tem mais, ta tudo no meio do mato, ninguém planta nada. Qué come quarque coisa...não tem.

...esses pessoal (da comunidade) num são mais de plantá são mais da pescaria num sabem nem como que se planta mais.

Nesse contexto, a dedicação exclusiva à pesca ocorreu pelo desaparecimento das práticas agrícolas - entre as décadas de 50 e 80 - em função da baixa fertilidade natural dos solos, pela falta de apoio à atividade, por restrições impostas pela legislação incidente no uso do solo, e também pela intensificação da pesca comercial. Já atividades acessórias, como o extrativismo vegetal e a caça (complementar da dieta alimentar), encontram-se coibidas há pelo menos duas décadas, de acordo com 
regulamentações da legislação ambiental vigente (CU. NHA; ROUGELLE, 1989; ZANONI; MIGUEL, 1995).

Também a migração de agricultores do interior para as comunidades ribeirinhas, para tornarem-se pescadores artesanais é um fato marcante na atual formação das comunidades, fenômeno esse que começa no final do século passado e se prolonga até os anos 90 .

...Porque lá tava difícil, não quiseram vivê mais lá (na margem do Rio Buqüera), quiseram saí pra beira da praia, daí vieram pra cá. Daí aqui que começaram a pescá, porque lá era só lavora...

...Aqui (em Amparo) era só peixe, camarão e lenha e arroz, no tempo do arroz. Plantava o arroz aí. 40-50 saco...tudo isso aí tudo esses morro por ai foram cultivado de lavora no tempo que nós cheguemo aqui quando viemo lá do Buqüera...depois veio mais gente pra praia...vieram vindo pra cá. Aqui...num tinha ninguém aqui, depois que vieram vindo...muita gente.Que aqui era um lugar mais falado que tinha.

Atualmente, o pescador artesanal das baías paranaenses utiliza principalmente mão-de-obra familiar, canoas a motor e a remo e outros apetrechos simplificados. Seus produtos principais são o camarão e o peixe, sendo que a extração de ostras e a captura de caranguejos e siris são atividades que se somam na tentativa de suprir o cotidiano da sobrevivência (IPARDES, 2001). Também têm enfrentado diversos tensores na manutenção de seu modo de vida, sejam eles: a presença de uma expressiva frota empresarial, cuja atividade na plataforma costeira tem afetado diretamente a pesca artesanal estuarina; de pólos industriais, de atividades dos Portos de Paranaguá e Antonina; a expansão do turismo e do processo de urbanização no entorno dos atuais centros urbanos; a especulação imobiliária; o desenvolvimento de atividades pecuárias; e o estabelecimento de diversas Unidades de Conservação na região (CUNHA; ROUGELLE, 1989; ANDRIGUETTO FILHO, 1999).
É nesse contexto de crise da pesca artesanal e de pauperização gradativa deste contingente humano que os recursos bênticos de manguezais têm tomado importância crescente. A mobilização da economia familiar para esta atividade se resume na expressão comumente usada pelos pescadores artesanais:

... a turma tá cada vez mais caindo no mangue, por que não tem mais para onde correr...!

Nesse processo histórico, os recursos de manguezais passaram a ter importância crescente na economia familiar, quanto maior tornava-se a dependência da atividade pesqueira.

O mangue agora na vida do pescador tem muita importância.

Mas se tivesse a produção que tinha antes né.

Porque antes tinha e ninguém mexia nele, bem poucas pessoa.

E agora, querem mas não tem. Porque daonde se tira e não se põe, é claro que faz falta.

E aquilo não se cria de repente não. Isso custa a se criar ali.

\section{Os manguezais do Complexo Estuarino da Baía de Paranaguá}

A atual política pública, que confere aos manguezais ${ }^{14}$ a característica de res communes e aos recursos de sua fauna ${ }^{15}$ a de res nullius, tem causado conflitos crescentes de uso, principalmente pela falta de um ordenamento regulador do acesso aos territórios e aos recursos nesses ecossistemas. A atual legislação brasileira e estadual de proteção a esses ecossistemas está embasada na concepção ecológica simplificadora que entende os ecossistemas de manguezais como unidades

14 São áreas de proteção permanente (Lei 4.771, do Código Florestal, artigo 2, de 15 de setembro de 1965), pertencem à União, sendo inalienáveis, públicos e de uso comum (Constituição Federal, 1988) e considerados terrenos da Marinha (Lei n. ${ }^{\circ} 9.760$, de 05 de setembro de 1946); na legislação federal, pertencem à categoria de terras e zonas úmidas, protegidos pelo Decreto-lei n. ${ }^{\circ} 33$ (16 de junho de 1992), que aprova a convençāo de Ramsar, sobre zonas úmidas de importância internacional (PARANÁ, 1996, I-33, p. 1, apud CANEPARO, 1999).

15 Os recursos da fauna explorados comercialmente nos manguezais paranaenses são principalmente ostras (Crassostrea rhizophorae), caranguejos-uçá (Ucides cordatus) e sururús (Mytella guyanensis). Dentre eles, apenas as populaçōes de $U$. cordatus tem regulamentação de uso por meio de portarias federais e estaduais específicas. 
produto de um movimento histórico da pesca combinada a outras atividades.Esse estudo de caso valeu-se de diversas metodologias, como a elaboração de diagnósticos gerais sobre as dinâmicas de apropriação dos recursos de manguezais, histórias de vida dos pescadores artesanais, saberes comunais e mapas cognitivos sobre as heterogeneidades dos bosques e da distribuição dos recursos da fauna nos manguezais, estudos ecológicos de campo sobre a fisiografia de determinados locais no Complexo Estuarino, e sobre a distribuição e abundância dos três recursos da fauna apontados como importantes economicamente, a saber, Ucides cordatus (o caranguejo-uçá), Crassostrea rhizophorae (a ostrado-mague) e Mytella guyanensis (o sururú). Essa pesquisa organizou-se em duas grandes etapas: $1^{\circ}$. Diagnóstico geral dos modos de apropriação dos manguezais de todo o Complexo Estuarino, e $2^{\circ}$. Estudos de caso, nas comunidades de Amparo (Estuário da Baía de Paranaguá) e Poruquara (Baía dos Pinheiros), considerando os saberes comunais e modos de apropriação dos bosques locais, bem como estudos ecológicos sobre a fisiografia local e a abundância dos recursos faunísticos de interesse neste estudo.

Embora o trabalho ainda esteja em andamento, alguns resultados já permitem ilustrar alguns saberes comunais articulados aos modos de apropriação, que exemplificam alguns ajustamentos adaptativos às condições socioambientais. Foram realizadas 53 entrevistas abertas com pescadores artesanais e comerciantes de pescado, entre dezembro de 2002 e agosto de 2003. Essa pesquisa abrangeu os distintos setores do Complexo da Baía de Paranaguá, compondo um universo de 31 localidades, dentre elas, 29 vilas pesqueiras, o balneário de Pontal do Sul, e o mercadinho das ostras de Paranaguá.

As entrevistas, individuais e coletivas, ocorreram tanto em terra, em visita às residências e outros estabelecimentos das vilas, quanto nas embarcações, durante atividades pesqueiras, e outras, realizadas no mercado público de pescados de Paranaguá. As entrevistas foram sua maioria, registradas em gravador, com a devida autorização dos entrevistados. Após sua realização, aquelas registradas foram transcritas em totalidade, respeitando a estrutura lingüística do discurso dos entrevista- dos, e posteriormente as informações específicas foram tratadas taxonômicamente.

Para compreender a relação histórica desses pescadores com o ambiente como um todo e com os manguezais, em primeiro lugar, far-se-á uma incursão na literatura, ilustrando-a com histórias de vida coletadas durante o estudo (veja-se também o trabalho de Andriguetto Filho, neste volume).

\section{Uma breve história dos pescadores artesanais paranaenses}

Ao longo dos anos, esses grupos humanos passaram de uma atividade de subsistência, para a pequena produção de pescadores-lavradores, e finalmente para a atual condição exclusiva de pescadores artesanais (DIEGUES, 1983; CUNHA; ROUGELLE, 1989). Seguem relatos de histórias de vida de idosos da Comunidade de Amparo:

Minha mãe trabalhava na roça, trabalhava na roça, era pescador e trabalhava na roça, é por isso que comida não faltava, meu pai trabalhava na roça, meu pai era pescador, minha mãe, trabalhando em lavoura...

O pessoal aqui plantava muito, aqui era o arroz, era a banana...Agora nem tem mais, ta tudo no meio do mato, ninguém planta nada. Qué come quarque coisa...não tem.

...esses pessoal (da comunidade) num são mais de plantá são mais da pescaria num sabem nem como que se planta mais.

Nesse contexto, a dedicação exclusiva à pesca ocorreu pelo desaparecimento das práticas agrícolas - entre as décadas de 50 e 80 - em função da baixa fertilidade natural dos solos, pela falta de apoio à atividade, por restrições impostas pela legislação incidente no uso do solo, e também pela intensificação da pesca comercial. Já atividades acessórias, como o extrativismo vegetal e a caça (complementar da dieta alimentar), encontram-se coibidas há pelo menos duas décadas, de acordo com 
regulamentações da legislação ambiental vigente (CUNHA; ROUGELLE, 1989; ZANONI; MIGUEL, 1995).

Também a migração de agricultores do interior para as comunidades ribeirinhas, para tornarem-se pescadores artesanais é um fato marcante na atual formação das comunidades, fenômeno esse que começa no final do século passado e se prolonga até os anos 90.

...Porque lá tava difícil, não quiseram vivê mais lá (na margem do Rio Buqüera), quiseram saí pra beira da praia, daí vieram pra cá. Daí aqui que começaram a pescá, porque lá era só lavora...

...Aqui (em Amparo) era só peixe, camarão e lenha e arroz, no tempo do arroz. Plantava o arroz aí.. 40-50 saco...tudo isso aí tudo esses morro por aí foram cultivado de lavora no tempo que nós cheguemo aqui quando viemo lá do Buqüera...depois veio mais gente pra praia...vieram vindo pra cá. Aqui...num tinha ninguém aqui, depois que vieram vindo...muita gente.Que aqui era um lugar mais falado que tinha.

Atualmente, o pescador artesanal das baías paranaenses utiliza principalmente mão-de-obra familiar, canoas a motor e a remo e outros apetrechos simplificados. Seus produtos principais são o camarão e o peixe, sendo que a extração de ostras e a captura de caranguejos e siris são atividades que se somam na tentativa de suprir o cotidiano da sobrevivência (IPARDES, 2001). Também têm enfrentado diversos tensores na manutenção de seu modo de vida, sejam eles: a presença de uma expressiva frota empresarial, cuja atividade na plataforma costeira tem afetado diretamente a pesca artesanal estuarina; de pólos industriais, de atividades dos Portos de Paranaguá e Antonina; a expansão do turismo e do processo de urbanização no entorno dos atuais centros urbanos; a especulação imobiliária; o desenvolvimento de atividades pecuárias; e o estabelecimento de diversas Unidades de Conservação na região (CunHA; ROUGELLE, 1989; ANDRIGUETTO FILHO, 1999).
É nesse contexto de crise da pesca artesanal e de pauperização gradativa deste contingente humano que os recursos bênticos de manguezais têm tomado importância crescente. A mobilização da economia familiar para esta atividade se resume na expressão comumente usada pelos pescadores artesanais:

... a turma tá cada vez mais caindo no mangue, por que não tem mais para onde correr...!

Nesse processo histórico, os recursos de manguezais passaram a ter importância crescente na economia familiar, quanto maior tornava-se a dependência da atividade pesqueira.

O mangue agora na vida do pescador tem muita importância.

Mas se tivesse a produção que tinha antes né.

Porque antes tinha e ninguém mexia nele, bem poucas pessoa.

E agora, querem mas não tem. Porque daonde se tira e não se põe, é claro que faz falta.

E aquilo não se cria de repente não. Isso custa a se criar ali.

\section{Os manguezais do Complexo Estuarino da Baía de Paranaguá}

A atual política pública, que confere aos manguezais ${ }^{14}$ a característica de res communes e aos recursos de sua fauna ${ }^{15}$ a de res nullius, tem causado conflitos crescentes de uso, principalmente pela falta de um ordenamento regulador do acesso aos territórios e aos recursos nesses ecossistemas. A atual legislação brasileira e estadual de proteção a esses ecossistemas está embasada na concepção ecológica simplificadora que entende os ecossistemas de manguezais como unidades

14 São áreas de proteção permanente (Lei 4.771, do Código Florestal, artigo 2, de 15 de setembro de 1965), pertencem à União, sendo inalienáveis, públicos e de uso comum (Constituição Federal, 1988) e considerados terrenos da Marinha (Lei n. ${ }^{\circ} 9.760$, de 05 de setembro de 1946); na legislação federal, pertencem à categoria de terras e zonas úmidas, protegidos pelo Decreto-lei n. 33 (16 de junho de 1992), que aprova a convenção de Ramsar, sobre zonas úmidas de importância internacional (PARANÁ, 1996, I-33, p. 1, apud CANEPARO, 1999).

15 Os recursos da fauna explorados comercialmente nos manguezais paranaenses são principalmente ostras (Crassostrea rhizophorae), caranguejos-uçá (Ucides cordatus) e sururús (Mytella guyanensis). Dentre eles, apenas as populações de $U$. cordatus tem regulamentação de uso por meio de portarias federais e estaduais específicas. 
FIGURA 01 - LOCALIZAÇÃO DAS FORMAÇÕES REGIONAIS DE MANGUEZAIS NO COMPLEXO ESTUARINO DA BAÍA DE PARANAGUÁ. AS SETAS INDICAM OS DESLOCAMENTOS DE GRUPOS EXTRATIVISTAS PARA A COLETA DE CARANGUEJO-UÇÁ, E DE OSTRA-DO-MANGUE. OS CÍRCULOS INDICAM AS ÁREAS DE MANGUEZAIS COM MAIOR PROCURA OU DE ACESSO RESTRITO.

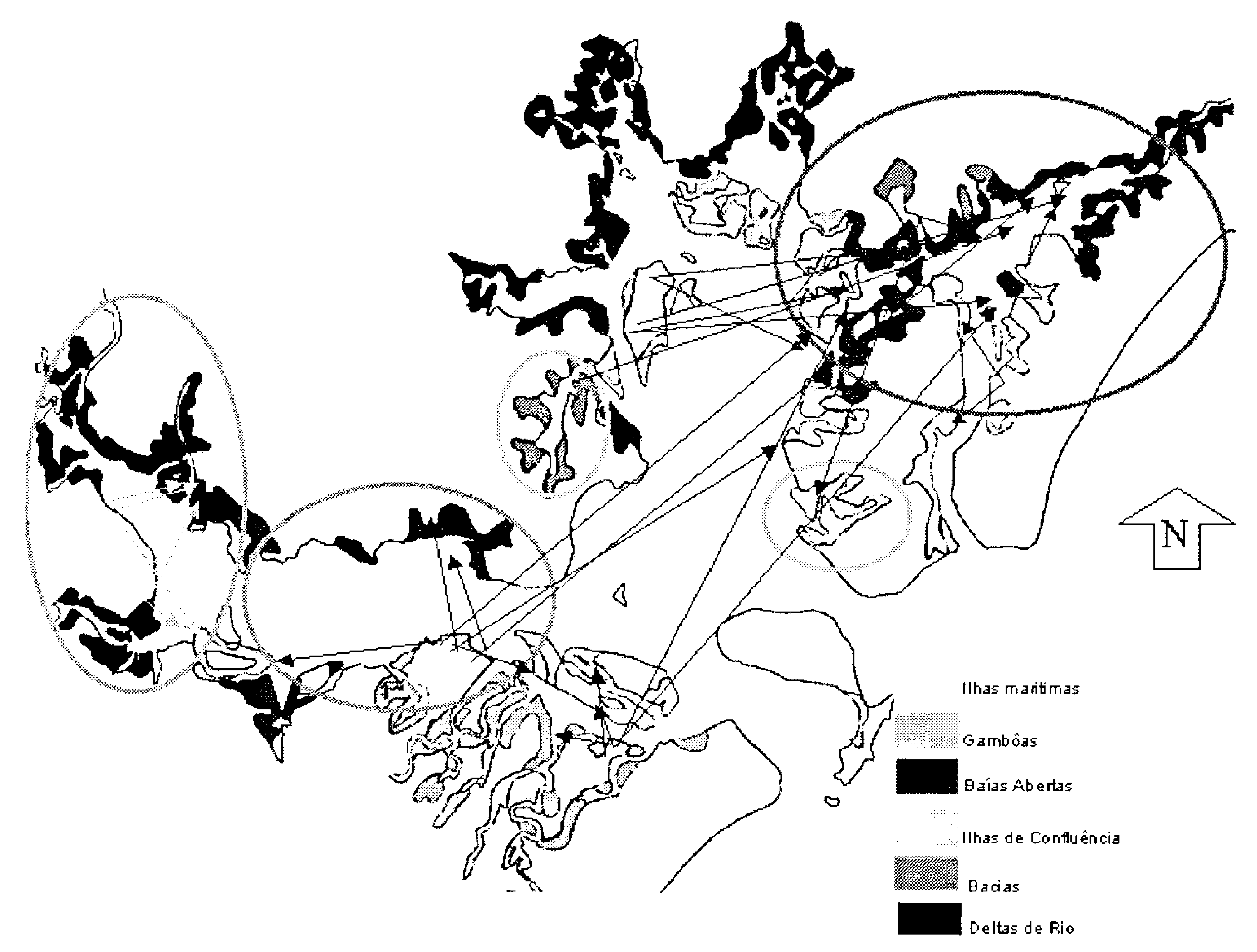

Fonte: adaptado de Martin (1992). Escala 1:25:000

homogêneas (KJERVE; LACERDA, 1993; IPARDES, 2001), tanto estrutural quanto funcionalmente.

Entretanto, diversas contribuições acadêmicas apontam para importantes padrões de heterogeneidade desses ambientes. No caso dos manguezais do Complexo Estuarino da Baía de Paranaguá, componentes da Unidade VII na classificação de Schaeffer-Novelli (1989), existe uma marcante heterogeneidade estrutural espacial em seus bosques, constituindo tanto formações mono como multiespecificas, com estruturas fisiográficas que variam de mono a pluriestratificadas (MARTIN, 1992). Sua diferenciação estrutural e funcional os enquadra em 3 tipos gerais de formações locais: povoamentos subfrutescentes; povoamentos cerrados, e povoamentos de franja. Essa tipologia fitossociológica de Martin (1992) correlaciona a ocorrência desses distintos tipos fisiográficos a uma série de componentes funcionais que configuram ambientes diferenciados no Complexo Estuarino da Baía de Paranaguá, quais sejam, bacias, deltas de rios, ilhas de confluência, baías abertas, ilhas marítimas e gamboas, indicando 10 tipos fisiográficos distintos para os bosques de manguezais deste Sistema (figura 1).

Também Lana (no prelo) descreve padrões de distribuição da fauna que concordam com relatos de pescadores, os quais indicam maiores capturas de crustáceos e moluscos em manguezais estruturalmente mais desenvolvidos, particular- 
mente nas áreas mais internas da baía. A exemplo disso, seguem relatos coletados por Miranda (op cit.).

Pra cima da barra do rio do Itinguçú...Ahh... lá,o caranguejo, é mais grande.

É, mais graúdo. Pra cima e pra baixo ali o caranguejo é mais graúdo.

Agora esses mangue pra cá é mangue baixinho, já é sempre um mangue mais areiado né, ali já é caranguejo miúdo, e pouco tem.

Lá pro lado de Guaraqueçaba, pra lá, dá esse caranguejão assim, porque o mangue é alto, mole. Daí o caranguejo cria-se à vontade. Ai dá aqueles caranguejo grande... Superagui, lá pra trás.

Esses indicativos de uma possível heterogeneidade na distribuição e abundância da fauna dos manguezais, condicionada às heterogeneidades fisiográficas dos bosques, chamam atenção especial quando se pretende conhecer as relações de apropriação dos recursos de manguezais.

Ao caracterizar os modos de apropriação dos manguezais do Complexo Estuarino da Baía de Paranaguá, constatou-se que os pescadores artesanais reconhecem as heterogeneidades locais dos bosques de manguezais a partir de seus saberes comunais.

\section{Alguns saberes comunais sobre a fisiografia lo- cal}

Os pescadores artesanais reconhecem as três espécies de árvores que compõem bosques de manguezais do Complexo Estuarino da Baía de Paranaguá (Rhizophora mangle, Laguncularia racemosa e Avicenia schaueriana) além de atribuírem denominações locais que reconhecem a marcante heterogeneidade estrutural espacial desses ecossistemas. Esse conhecimento comunal corrobora os estudos científicos de Martin (1992).

Rhizophora mangle é conhecida localmente como Canapuva, ou Canapuba, e o bosque em que ocorre com dominância é denominado de Canapuval. Essa ár- vore possui um pigmento vermelho (tanino) empregado ainda na impermeabilização de redes de pesca na região.

Laguncularia racemosa é conhecida localmente como Mangue Manso, e a mesma denominação é dada para o bosque em que esta espécie ocorre com relativa dominância. Também, os extrativistas se referem a esses bosques de $L$. racemosa, como bosques baixos, embaraçados, difíceis de andar. A denominação de bosques baixos ou mansos faz referência a bosques denominados de anões por Lana (1998), que indicam, muitas vezes, formações monoestratificadas, e compõem nichos distintos, já identificados por Martin (1992); Lana (1998) e Brogim (2001) como ocorrendo principalmente nas regiões eurihalinas de alta energia da Baía de Paranaguá.

Avicenia schaueriana, conhecida localmente como Mangue Preto ou Siriúva, e a ocorrência de bosques com predominância dessa espécie, é denominado pelos extrativistas locais como Siriuval.

Assim como os bosques monoespecíficos recebem suas denominações locais, os bosques multiespecíficos, com co-dominância das três espécies nas áreas mais internas da baía (MARTIN, 1992; LANA, 1998. BROGIM, 2001) e variadas estruturas fisiográficas, também são reconhecidos pelos pescadores artesanais, que se referem a eles como bosques misturados, sendo que ao apresentar dosséis altos, são qualificados de: mangues fáceis, espaçosos; a turma gosta de mangue alto, espaçoso, alto, firme, desembaraçado!, bons de correr e de tirar. ${ }^{16}$

Ainda, a associação das formações arbóreas dos manguezais com distintos ambientes geomorfológicos no Complexo Estuarino da Baía de Paranaguá, como bacias, deltas de rios, ilhas de confluência, baías abertas, ilhas marítimas $e$ gamboas, estabelecem 10 tipos fisiográficos diferentes que também se apresentam incorporados no conhecimento dos pescadores artesanais, e parecem condicionar os processos de apropriação dos recursos de manguezais.

No Guapicum o mangue é bonito, é só mangue alto, de raiz (escora) que parece uns dedos. A turma gosta, rapaz! De mangue alto, espaçoso...

16 Correr refere-se a coletar Ucides cordatus de forma manual, durante os fenômenos da andada ou corrida, na lua do caranguejo, cuja produção é nomeada como o caranguejo pegado; tirar refere-se a coletar caranguejo com algum instrumento de captura (foice ou cavadeira, e lacinhos), cuja produção é denominada caranguejo tirado. 
Eu fazia que o caranguejo grosso era do mangue espaçoso, mas tem mangue baixo, manso, que tem caranguejo grosso.

Tem mangue que é só caranguejo graúdo. Tem mangue que é " criame”, ele choca ali, tem só filhotes. Regula com a altura e com a dureza do mangue.

Mangue que tem só filhotes a gente nem vai. $O$ caranguejo miúdo ninguém nem qué nem pra comer. No mangue mais mole tem do grosso. No mangue mais areado tem os filhotes.

Os bosques de Deltas de Rios demonstram ter uso mais localizado, e seu acesso parece estar condicionado às pequenas embarcações, presentes na Baia de Antonina, enseadas do Itaquí e Benito; os bosques de Ilhas Marítinas têm sido apontados como de produtividade variada, a exemplo disso, os bosques da Ilha da Cotinga são considerados atualmente como de média ou baixa produtividade, devido à exploração continuada de ostras do mangue e caranguejo, e a baixa ocorrência de sururús, enquanto que nos bosques em Ilhas Marítimas da Ilha das Peças, e Baía dos Pinheiros é relatada alta produção desses recursos, sendo que caso nos bosques próximos à comunidade da Ilha das Peças existem formas de regulação comunal; os bosques de Bacia demonstram ser explorados principalmente pelas comunidades mais próximas (Comunidades da Enseada do Medeiros, e Comunidades do Poruquara e Sebuí); também os bosques de Gamboas têm apresentado um uso mais local. Os bosques de Ilhas de Confluência indicam ter alta a média produtividade, a exceção daqueles sito à Ilha Rasa, cujos relatos demonstram um decréscimo de oferta de recursos (principalmente de caranguejos "graúdos) devido à exploração local. Por fim, os bosques de Baías Abertas têm sido o tipo fisiográfico regional mais procurado por grupos extrativistas que se deslocam a grandes distâncias na extração de caranguejos e ostras (principalmente em bosques na Baía dos Pinheiros).

Essas heterogeneidades fisiográficas regionais, por sua vez, condicionam tanto o acesso dos grupos extrativistas, quanto as diferentes maneiras de uso efetivadas na extração dos recursos da fauna. Assim, relatos desses extrativistas apontam para uma complexa dinâmica dos modos de apropriação desses manguezais em todo o Complexo Estuarino.
Com o fim de ilustrar essa dinâmica serão exemplificadas aqui algumas relações de apropriação dos bosques de manguezais, ficando as especificidades das dinâmicas de apropriação dos recursos da fauna para um ensaio posterior. Entretanto, é importante ressaltar que, dentre os recursos explorados, o extrativismo de caranguejos e ostras é o que gera as grandes dinâmicas de deslocamento dos extrativistas aos diferentes bosques.

\section{Algumas relações de acesso aos bosques de manguezais}

No Complexo Estuarino da Baía de Paranaguá, pode-se distinguir duas grandes áreas de acesso à exploração dos recursos de manguezais: a primeira é a Baía de Antonina, explorada principalmente pelas próprias comunidades locais, nos manguezais de formação de Deltas de Rio (Faisqueira, Quatinga e Nhundiaquara), sendo que a maioria das comunidades pratica deslocamentos no extrativismo dos bosques, mesmo porque muitas delas se encontram próximas do centro urbano de Antonina.

Lá no Faisquera vai o pessoal do Portinho e Batel. E o mangue melhor é o Faisquera.

Também é que pra cá não é muito perigoso, no Teixeira é (perigoso) por causa do vento (pescador da Comunidade da Ponta da Pita).

A outra grande área de exploração engloba toda a região restante do Complexo Estuarino da Baía de Paranaguá, com focos específicos de maior pressão de uso, quais sejam:

a) os bosques de formação em Baía Aberta às imediações de Amparo, Eufrasina e Europinha, cujo uso ocorre tanto pelas comunidades locais como pelas vilas urbanas de Valadares e de Vila Guarani;

b) outro foco de pressão de uso intensamente relatado nos estudos de campo diz respeito às imediações de Guapicum, cujas formações dos bosques de manguezais são do tipo de Ilhas de Confluência e Baías Abertas, e toda a área ao norte da Baía dos Pinheiros, com formações regionais de bosques de manguezais do 
tipo Baías Abertas, com pequenas áreas de formação em Bacias (Poruquara e Sebuí).

A pressão de exploração nesse último foco apresenta-se como um fenômeno relativamente recente de deslocamento do contingente extrativista para essa região norte (Baía dos Pinheiros e Laranjeiras), que tem sido condicionado pela possibilidade de coletar animais com maiores tamanhos e pela facilidade de acesso permitido pelas fisiografias locais.

O mangue aqui o caranguejo é miúdo, aqui por perto a gente só pega na corrida.

Nesses parques por aqui ninguém nem vai pegar caranguejo, aqui a gente só pega quando corre, escolhe os mais graúdos. Mas a gente vai mesmo é para Canudal.

A gente sai cedo pra pegar porque fica longe, pra arrancar do buraco entre as luas, a gente vai pro lado do Canudal, pra lá, baía dos Pinheiros, Guapicum pra frente. São mangue grande ali o pessoal quase não trabalha. È mangue alto, firme, desembaraçado, a gente pega preço bom lá. (pescador da Comunidade da Ponta da Mariana/Ilha Rasa)

Ao recorrer aos estudos de Martin (1992), identifica-se uma similaridade entre a área preferencial da região de Amparo e aquela da Baía dos Pinheiros (proximidades do Guapicum), que é a presença majoritária de manguezais do tipo Baías Abertas. Esses tipos de formações regionais têm alguns povoamentos excepcionais de "Fourrés" na denominação francesa, frutescente e subfrutescente (os mangues baixos ou medianos, na maioria monoespecíficos, com dossel entre 2 a 4 metros); mas principalmente muitos bosques com características fisiográficas do tipo Foret e Haut Fourre na denominação francesa, ou seja, bosques com mais de $5 \mathrm{~m}$ de altura do dossel, que podem ser pluri ou monoespecíficos, pluri ou monoestratificados e são identificados pelos pescadores como bosques altos, desembaraçados, bons de correr.

Além disso, provavelmente o acesso a essas formações em Baías Abertas deve ser muito mais fácil quando comparados àquele aos Deltas de rios, por exemplo, devido às condições do ambiente deposicional na formação de baixios. Navegar nos baixios necessita o co- nhecimento da localização desses bancos de sedimentos, e também o entendimento das marcações feitas pelos pescadores para identificar os canais de acesso, sendo que em muitos desses ambientes, em determinadas porções desses rios, não é possível passar com "voadeiras" com motor de popa ou outras embarcações que não sejam a remo.

Parece haver, então, um redirecionamento de território de exploração, principalmente em se tratando dos grupos extrativistas do Valadares e da Vila Guarani que se deslocam a grandes distâncias e que anteriormente exploravam mais os manguezais da região de Amparo, e agora estão priorizando os bosques para os lados do Guapicum. Isto se deve à diminuição de tamanho dos caranguejos e ostras desses manguezais do Estuário da Baía de Paranaguá, mas também à preferência de fisiografias em Baías Abertas e pela oferta de recurso com maior tamanho de captura na Baía dos Pinheiros.

Aqui não tem caranguejo graúdo...

Lá no Guapicum é dos criado...

Na minha infância tinha aqui dos graúdos... Não sobra dos grande pra correr, porque o pessoal tira da toca os grande, e vai ficando pequeno... (pescador da comunidade de Amparo)

Esse deslocamento é percebido também na atividade extrativista das comunidades da Ilha Rasa, Medeiros de Baixo, e Maciel, para a exploração de caranguejos e ostras nos bosques "pra lá do Guapicum".

Agora pra cá pro nosso lado, nesse manguezal aí, Deus do céu. Umas buraqueira muito grande.

A turma tira muito. Estraga muito o mangue. De um ano para o outro a gente vê diferença de um para o outro, quando o mangue está bem estragado, vem menos caranguejo.

Agora a turma que eles costumam tirar o caranguejo, pega com aquele lacinho, que eles inventaram aí, pra eles o caranguejo é o ano inteiro, pra eles não falta; e é uma coisa que prejudica muito o mangue. Estraga muito o mangue.

Nóis já falamo, a gente fala, fala pra essa turma aí (pessoal do Ibama e da florestal) mas não adianta né. (pescador da comunidade do Guapicum - Ilha das Peças) 
O acesso ao território e a exploração dos espaços extrativistas nos manguezais parecem estar condicionados ao conhecimento específico das fisiografias dos bosques e das ofertas relativas dos recursos. Entretanto, ainda há que se considerar nessa análise outros condicionantes físicos e biológicos do ambiente explorado, as relações familiares e de compadrio, os controles de acesso praticados por algumas comunidades e pelos órgãos fiscalizadores, técnicas de coleta, demanda do mercado consumidor e as estratégias temporais da atividade de pesca artesanal.

\section{Alguns controles comunais de acesso aos territórios}

É interessante ressaltar que, apesar dos manguezais estarem formalmente na condição de livre acesso, em determinadas regiões do Complexo Estuarino da Baía de Paranaguá, existem algumas regulações territoriais.

A exemplo disso, têm-se relatos de um controle efetuado pela comunidade da Ilha das Peças aos seus manguezais locais, principalmente àqueles do rio das Peças. Segundo os pescadores da comunidade de Peças e de outras comunidades, como as do Poruquara, Guapicum, Medeiros, parece haver uma concessão de uso apenas para determinados grupos oriundos de outras comunidades, como a comunidade do Poruquara, que tem tido permissão para extrair ostras juvenis desses bosques do rio das Peças. Já o acesso para algumas comunidades, como a do Valadares e do Almeida, tem recebido restrições de uso, tanto para a coleta de ostras e caranguejo, quanto de outros recursos pesqueiros.

Ao questionarem-se os critérios de concessão de uso para determinados grupos coletores, o que se apontou foi que as práticas de extrativismo dos grupos aos quais são concedidos os acessos eram menos predatórias (extração por faquinha, para a ostra, por exemplo) que daqueles outros grupos, como do Valadares, Medeiros de Baixo, e Almeida, os quais costumam usar a foice ou laço para a extração do caranguejo, e arrancar a raiz da Canapuva (Rhizophora mangle) para a extração de ostras.

dá caranguejo graúdo aqui, ele dá bem.

Olha aqui (o pessoal) não prejudica não, mas pro lado do Canudal ali prejudica
(...)O pessoal ali do Valadares eles tiraram muito caranguejo, que é de corta (da foice)

já há uns 3 anos pra cá... Tem parte que a turma não deixa né.

Aqui, o pessoal reclama (se for) de cavadeira

Vem, pessoal do Valadares, Vila Guarani.

(de um ano pro outro) sente a diferença.

Também outro relato de controle de acesso faz referência à Enseada do Medeiros. De acordo com as diversas entrevistas realizadas, os manguezais dessa região têm sido utilizados apenas pelas comunidades do interior da Enseada, ou seja, Medeiros de Baixo, Medeiros de Cima e Vila São Miguel. Todavia, existem relatos de deslocamento do grupo de Medeiros de Baixo, para a extração de ostras e caranguejos em outros manguezais distantes de sua vila de origem.

Lá pro lado do Almeida, praquele lado lá a senhora vai no mangue e lá a senhora não vai encontrar I caranguejo. O único lugar que encontra e lá no Medeiros, no Medeiros eles não deixam tirar de maneira nenhuma.

A turma da vila (do Medeiros) cuida do manguezal lá, lá pra dentro daquele rio ninguém entra não. Lá é só eles. Lá eles tão unido viu, eles falava com a turma e se a turma não obedecesse, eles mete o cacete. Lá é fogo. Só que aqui, a gente não... A vila é pequena, não tem muita gente pra reunir. (comunidade do Guapicum - Ilha das Peças)

Ao analisar os tipos regionais de bosques de manguezais que têm tido controle de acesso (Enseada do Medeiros e Rio das Peças), constata-se que são justamente aqueles posicionados geograficamente próximos às comunidades pesqueiras, as quais têm visibilidade para o acesso físico dos barcos dos extrativistas. Observa-se que, tanto para o rio das Peças quanto para a Enseada do Medeiros, existe uma entrada relativamente estreita e a proximidade visual da comunidade logo a essa entrada.

Aqui no nosso mangue vem gente de todo lado tirar caranguejo. A turma de Paranaguá parte tudo pra cá pra esse lado, é muito aberto aqui, muito manguezal. É difícil de cuidar. 
Lá é um rio. Lá no Medeiros, é só uma boca de rio. Lá é estreitinho, qualquer um que entrar pra lá eles estão vendo, aí eles vão atrás e mandam o cara sair... (comunidade do Guapicum - Ilha das Peças)

É verdade que o pessoal do Medeiros cuida, não deixa entrar no mangue?

É. Não deixa entrar não. A turma tenta, mas o pessoal vai lá conversar, e não deixa. Senão acaba com tudo. Ali dá, dá pra ver quem entra de fora. (pescador do Medeiros de Baixo)

Essas comunidades parecem ter uma organização social que permite a condução de processos decisórios quanto a essas determinações de acesso. $\mathrm{Na}$ vila da Ilha das Peças, por exemplo, a presença de associações de moradores, mulheres e pescadores, parece estar gerando uma determinada união dos pescadores que levou à tomada de decisão sobre restrição de acesso para as outras comunidades, tanto para a prática de extrativismo em manguezais, quanto para a pesca. Já na comunidade do Medeiros de Baixo, além dessa regulação de acesso, percebeu-se também uma articulação nos modos de produção pesqueira local, para a absorção de aportes tecnológicos de cultivo de ostras, mediados por instituições como a Emater. Também apresentam no extrativismo de caranguejos, o uso do cerco e cata por encomenda, utilizando tanto a vazão da produção através do Mercado de Paranaguá, quanto de Guaratuba.

\section{Elementos de conclusão}

As dinâmicas de apropriação dos recursos bênticos de manguezais no Complexo Estuarino da Baía de Paranaguá apresentam-se profundamente articuladas com os saberes comunais sobre as fisiografias locais, e com o conhecimento específico sobre a abundância, distribuição e outros aspectos da biologia da fauna explorada comercialmente nesses bosques.

Assim, mesmo que a atual legislação brasileira e estadual de proteção aos manguezais esteja embasada em uma concepção ecológica simplificadora que entende esses ecossistemas como unidades homogêneas, os pescadores artesanais reconhecem suas distintas fisiografias locais e com elas interagem a ponto de condicionar seus modos de apropriação dos recursos bênticos de maneira dinâmica e interdependente.

Quanto à regulação de território, apesar dos manguezais estarem legalmente na condição de livre acesso, em algumas regiões deste Complexo Estuarino eles têm sido apropriados de maneira comunitária, com controle de acesso específico para alguns grupos extrativistas. Isso tem ocorrido principalmente pela escassez de ostras e caranguejos em determinados bosques de manguezais, fato esse que tem ocasionado deslocamentos de extrativistas (principalmente aqueles oriundos de vilas urbanas) para outros bosques, afetando, conseqüentemente, a atividade extrativista de outras comunidades pesqueiras. A apropriação comunal também é uma resposta às práticas extrativistas que causam prejuízo ao ambiente, como a coleta de caranguejos com foice, causando buracos no solo dos manguezais; o uso de lacinho, apetrecho esse que muitas vezes é abandonado no ambiente, vindo a matar muitos caranguejos; e a coleta de ostras arrancadas, ou seja, com a extração de raiz da Canapuva ( $R$. mangle).

O comportamento de restrição de território observado nessas comunidades é pontual no Complexo Estuarino, mas parece similar ao padrão apontado por Berkes (1989), Peck e Feldman (1986). Também é necessário relatar que nessas partilhas de território, as relações de parentesco e compadrio são igualmente importantes para a compreensão dos comportamentos de regulação e de tolerância de acesso aos recursos.

Além disso, as atividades extrativistas em manguezais neste Complexo Estuarino parecem estar condicionadas às ofertas dos recursos bênticos de manguezais, relativas às fisiografias distintas das configurações meso e microrregionais e à capacidade específica das tecnologias de exploração desses recursos segundo os condicionantes físicos e biológicos dos bosques.

A pesca artesanal e o extrativismo da fauna bêntica em manguezais na região têm funcionado como um todo integrado, no qual as dinâmicas espaciais e temporais dos recursos provocam apropriações complexas das comunidades. As relações simbólicas e materiais dessas comunidades com as heterogeneidades dos ecossistemas e seus recursos condicionam uma dinâmica de relações socioambientais marcada por interdependências ecológicas, econômicas e socioculturais, embasadas em relações ora de solidari- 
MIRANDA, R. B. As relaçöes sociedade/ natureza sob a...

edade, ora de rivalidade, tanto intra como intergrupais. Essas dinâmicas de relações sociais condicionam, por sua vez, tanto a apropriação dos territórios quanto dos recursos e se refletem nos fluxos econômicos da atividade e nos impasses de regulação territorial.

Entretanto, a maneira genérica da atual forma de regulação legal sobre os manguezais e de seus recursos da fauna, segundo os pescadores artesanais do Complexo Estuarino da Baía de Paranaguá, tem gerado uma falta de regulação efetiva sobre as distintas maneiras de uso bem como de regulação de acesso aos territórios específicos de extração, condicionados aos mosaicos das heterogeneidades dos bosques neste Complexo Estuarino. Essa falta de regulação efetiva das diferentes práticas de extração impossibilita o manejo real dos recursos, bem como o estabelecimento de regras e códigos de ética de comportamento entre os grupos extrativistas.

O pessoal do Almeida chega a ir lá pro Ariri.

E se a gente falar alguma coisa eles vão achar ruim, então o pessoal não fala nada...

Mas pro mangue voltar ao normal, é de um ano pra frente. Ali tem um rio que chama Rio Fundo, eu fui ali não dava pra andar, tudo surucado, era só buraco." (pescador da Comunidade do Barbados)

Esses impasses de regulação de acesso e de uso dos recursos de manguezais, somados à constatação da diminuição dos tamanhos máximos capturados em bosques já muito explorados (como aqueles do Estuário da Baía de Paranaguá), e à precariedade do modo de vida atual dos pescadores artesanais (expostos à um mercado capitalista e à uma legislação ambiental restritiva), têm agravado a crise de gestão dos recursos de manguezais desse Complexo Estuarino.

Toda a complexidade das dinâmicas de apropriação dos manguezais do Complexo Estuarino da Baía de Paranaguá, bem como maiores detalhamentos a respeito de ajustes de co-evolução dos sistemas social e natural ainda carecem de estudos mais extensos e aprofundados. Entretanto, é imprescindível incorporar as lógicas comunais de apropriação desses ambientes na efetiva regulação e manejo legal de seus recursos.

\section{À guisa de novos instrumentais de análise}

O reconhecimento dos processos de co-evolução tem gerado um instrumental de análise das relações entre sociedades humanas e ambientes naturais de importância crescente, com o fim de compreender as interdependências dos sistemas social e natural.

É importante ressaltar aqui que muitas evidências de ajustamentos adaptativos vêm de processos desarmônicos, portanto é o estudo das dinâmicas desses ajustamentos que pode evidenciar padrões de resposta. Esses padrões de resposta podem não ser adaptativos em curto prazo, mas estar apontando para um potencial harmonizador futuro da problemática.

Assim, outra importante contribuição de Berkes (2002) e Berkes et al. (2002) diz respeito à expansão do conceito de resiliência ecológica, explanado ao início desse ensaio, ao somar a idéia de ajustamentos sociais aos condicionantes ambientais. Desta maneira, Berkes (2002) e Berkes et al. (2002) aplicam a idéia de resiliência no âmbito socioambiental, como resiliência socioecológica (SEIXAS, 2002). A base de um sistema de resiliência socioecológica é sua habilidade em responder aos feedbacks ambientais e absorver perturbações; sua habilidade de auto-organização; e sua capacidade de aprender e adaptar-se (RESILIENCE ALLIANCE, 2001; SEIXAS, 2002).

Em estudo de caso, Seixas (2002) evidencia a capacidade de regulação comunal e de resiliência socioambiental dos pescadores da Lagoa de Ibiraquera, $\mathrm{SC}$, demonstrando que seus modos de apropriação dos recursos passam por diferentes ciclos adaptados às distintas condições ambientais. Esses ciclos, por sua vez, coincidem com as fases de renovação de recursos, definidas pela tipologia de Holling (1986) e Gunderson et al. (1995), quais sejam: de liberação, de renovação, de exploração e de conservação.

Assim, a Lagoa de Ibiraquera passa por ciclos de abertura e fechamento de seu sistema hídrico em relação ao ambiente marinho, passando por diferentes períodos de ajustamentos em relação à sua biota. Seixas percebeu sincronias nos ciclos das populações de pescados, e nas atividades de pesca e seus distintos controles de acesso comunal e uso de recursos, que conferiam 
conservação para os recursos e determinada sustentabilidade para a atividade econômica.

O papel da organização cultural, neste contexto, é regular o uso de recursos para satisfazer as necessidades de seus membros. Processos simbólicos configuram mecanismos culturais que normatizam o acesso social à Natureza, determinando o desenvolvimento tecnológico e regulando ritmos de extração e transformação dos recursos. Da mesma forma, as relações de parentesco, as formas de reciprocidade, as organizações da propriedade comunal e os direitos territoriais favorecem a regulação do uso dos recursos naturais.

Esse acesso socialmente controlado à natureza se define através de tradições culturais que estabelecem as formas de uso da terra, de propriedade e manejo de recursos ambientais, as relações de gênero e idade, a divisão do trabalho e a distribuição de atividades produtivas (LEFF, 2000). Nessa perspectiva, a noção de patrimônio, bem como a gestão de um patrimônio natural, não prescinde da noção e da gestão de um patrimônio sociocultural.

Essa perspectiva aponta para uma noção de sustentabilidade, na qual devem ser considerados não só os aspectos materiais e econômicos, e os saberes hegemônicos e científicos, mas o conjunto multidimensional e multifacetado que compõe o fenômeno do desenvolvimento e a perspectiva da sustentabilidade: a sinergia de suas dimensões políticas, sociais, culturais e naturais.

Para Leff (2000), a emergência da referência do espaço provém da necessidade de enraizar a sustentabilidade em condições locais. Essa referência do espaço, por sua vez, funda-se na significação que imprime a Cultura à Natureza, onde o espaço e o lugar são resignificados a partir das identidades culturais, especificando as condições de sustentabilidade. Ao contrário, as lógicas acadêmicas logocentricas presentes nas atuais formas de gestão dos recursos naturais têm diluído os referentes geográficos e os sentidos culturais locais. Assim sendo, não se trata de dar suporte empírico e referências locais a uma racionalidade globalizadora, presente no discurso normativo do desenvolvimento sustentável, mas de abordar a sustentabilidade em seu caráter tanto "material-objetivo" quanto "simbólico-subjetivo".

Nesse processo de ajustamentos, as articulações produtivas de diferentes ecossistemas e territórios em comunidades tradicionais provêm da percepção da $\mathrm{Na}$ tureza como um processo sinérgico e integrado e não como um acervo de recursos como estoques ou mananciais. Assim, a Cultura é concebida como um princípio ativo para o desenvolvimento das forças produtivas, sob um paradigma alternativo de sustentabilidade, onde a produtividade ecológica e a inovação tecnológica estão entremeadas aos processos culturais que definem a produtividade social de cada comunidade; e estas, por sua vez, se enlaçam para gerar uma economia global alternativa, fundada nas forças produtivas da natureza e nos sentidos criativos da cultura (LEFF, 2000). A atenção às etnias e à revalorização da diversidade cultural passa a gerar uma nova compreensão das relações de alteridade, do objetivo com o subjetivo, do real e do simbólico, da cultura e da natureza (LEFF, 2000), em uma análise da cultura, onde se fundem o ideal e o material (GODELIER, 1984).

A viabilidade das populações humanas e dos ecossistemas dos quais elas extraem seus meios de subsistência são mutuamente, mas não exclusivamente, determinantes. Portanto, as decisões econômicas e sociais devem ser tomadas na busca da manutenção da viabilidade dos ecossistemas, e as decisões relativas à gestão dos meios naturais devem permitir a manutenção da viabilidade dos modos de vida correspondentes. Segundo Walters (1986), Henry (1987), Weber et al (1990) (apud: WEBER 1997), não existem soluções “ótimas", mas sim a elaboração de estratégias adaptativas, tanto em relação às variabilidades naturais, quanto às variabilidades econômicas e socioculturais.

Urge, então, uma efetiva democratização dos espaços de construção teórica e política a fim de incorporar às lógicas acadêmicas (que constroem a legalidade), as demais lógicas efetivadas na Relação Sociedade(s)/ Natureza(s), como condição essencial da possibilidade em descobrir e recriar saídas efetivas aos impasses das problemáticas socioambientais. 


\section{REFERENCIAS}

ANDRIGUETTO FILHO, J. M. Sistemas técnicos de pescae suas dinâmicas de transformação no litoral do Paraná, Brasil. Curitiba: 1999. 242 f. Tese (Doutorado) - Universidade Federal do Paraná.

BEGOSSI, A. Cooperative and territorial Resources: Brazilian Artisanal Fisheries. In: BURGER, J. et al. (Eds.). Protecting the commons. Washington, DC: Island Press Island Press, 2001. p. 109-130.

BERKES, F. Cooperation from the perspective of human ecology. In: BERKES, F. Common property resources. Ecology and community-based sustainable development. London: Belhaven Press, 1989. p. 70-88.

BERKES, F. Sacred ecology: traditional ecological knowledge and resource management. London: Taylor and Francis Press, 1999. 209 p.

BROGIM, R. Heterogeneidades estruturais, distribuição espacial e correlações entre a vegetação e gradientes ambientais em manguezais das Baías de Paranaguá e Antonina (Paraná). Curitiba, 2001. Tese (Doutorado) - Universidade Federal do Paraná.

CANEPARO, S. C. Manguezais de Paranaguá. Uma análise da dinâmica espacial da ocupação antrópica - 1952-1996. Curitiba, 1999. 289 f. Tese (Doutorado) - Universidade Federal do Paraná.

CAPRA, F. A teia da vida. 2. ed. São Paulo: Cultrix, 1997. $256 \mathrm{p}$.

CUNHA, L. H.; ROUGELLE, M. Comunidades litorâneas e unidades de proteção ambiental: convivência e conflitos; o caso de Guaraqueçaba. São Paulo: Nupaub-USP, 1989.

DIEGUES, A. C. O mito moderno da natureza intocada. 2. ed. São Paulo: Hucitec. 1998. 169 p.

DIEGUES, A. C. Repensando e recriando as formas de apropriação comum dos espaços e recursos naturais. In: DIEGUES, A. C.; MOREIRA, A. C. (Orgs.) Espaços e recursos naturais de uso comum. São Paulo: NUPAUB/USP. 2001.

DIEGUES, A. C.; ARRUDA, R. S. V. Saberes tradicionais e biodiversidade no Brasil. Brasília: Ministério Do Meio Ambiente/Nupaub-USP, 2001. (Série Biodiversidade, v. 4), 176 p.

FOLADORI, G. Los límites del desarrollo sustentable. Revista Trabajo y Capital, 224 p., 1999.
GODELIER, M. L'idéel et le materiel. Pensée, economies, sociétés. Paris: Fayard. 1984. 348 p.

GUNDERSON, L. H. Managing surprising ecosystems in Southern Florida. Ecological Econimics, n. 37, p. 371-378, 2001.

HOCHACHKA, P. W.; SOMERO, G. N. Biochemical adaptation. New Jersey: Princeton University Press, 1984. $538 \mathrm{p}$.

IPARDES. Zoneamento da APA de Guaraqueçaba. Curitiba: SEPL/ Ipardes, 2001. 150p.

JAPIASSÚ, H. A crise da razão e do saber objetivo. As ondas do irracional. São Paulo: Letras e Letras, 1996. 231 p.

KJERVE, B.; LACERDA, L. D. Mangroves of Brazil. In: LACERDA, L. D. , 1993. p. 245-272.

LANA, P. C. Políticas públicas, legislação ambiental e conflitos de uso: subsídios para uma gestão integrada dos manguezais da Baía de Paranaguá (Paraná, Brasil). Disponível em: $<w w w . r e i t o r i a . u f p r . b r / d o u t m e i o / l a n a . h t m>$. No prelo.

LEFF, E. Espacio, lugar y tiempo: la reapropriación social de la naturaleza y la construcción local de la racionalidad ambiental. Desenvolvimento e Meio Ambiente, n. 1, p. 57-69, jan./jun. 2000.

MAGNUM, C.; TOWLE, D. Physiological adaptation to unstable environments. Inconstancy of the internal milieu in an animal may be a regulatory mechanism. American Scientific, n. 65 , p. $67-75,1977$.

MARGULIS, L. Os primórdios da vida. Os micróbios têm prioridade. In: THOMPSON, W. I. (Org.). Gaia. Uma teoria do conhecimento. São Paulo: Gaia, 1990.

MARTIN, F. Étude de l'écosystéme mangrove de la Baie de Paranaguá (Paraná, Brèsil): Analyse des impacts et propositions de gestion rationnelle. Paris, 1992. $289 \mathrm{f}$. These (Doctorat) - Université Paris VII.

McCAY, B. J.; ACHESON, J. M. The question of the commons. The culture and ecology of communal resources. Tucson, USA: University Arizona Press, 1987. 439 p.

MIRANDA, R. B. Efeitos da temperatura e da salinidade sobre a tolerância e a ionorregulação de Chasmagnathus granulata Dana, 1851. Rio Grande, 1994. 176 f. Dissertação (Mestrado em Oceanografia Biológica) - FURG. 
ODUM, E. Fundamentos de ecologia. 4. ed. Lisboa: Fundação Calouste Gulbenkian, 1988.

PROSSER, C. L. General summary: The nature of physiological adaptation. In: PROSSER, C. L. (Ed.). Physiological adaptation. American Physiol. Society, Washington, p. 167$180,1958$.

RAYNAUT, C.; ZANONI, M.; LANA, P. C. O desenvolvimento sustentável regional: o que proteger? quem desenvolver? In: RAYNAUT, C. et al. Desenvolvimento e meio ambiente. Em busca da interdisciplinaridade. Curitiba: Ed. UFPR, 2002. p. 235-248.

SCHAEFFER-NOVELLI, Y. Perfil dos ecossistemas litorâneos brasileiros, com especial ênfase sobre o ecossistema manguezal. São Paulo: Instituto Oceanográfico da USP, 1989. $16 \mathrm{p}$.

SEIXAS, C. S. Social-ecological dynamics in management systems: investigating a coastal lagoon fishery in Southern
Brazil. Winnipeg, 2002. 265 f. Tese (Doutorado) - University of Manitoba, Canada.

SPARRE, P.; VENEMA, S. C. Introdução à avaliação de peixes tropicais. Parte 1-Manual. Roma: FAO, 1997. Documento técnico sobre as pescas, n. 306/1, , 404 p.

THOMPSON, W. I. As implicações culturais da nova biologia. In: THOMPSON, W. I. (Org.). Gaia. Uma teoria do conhecimento. São Paulo: Gaia, 1990.

WEBER, J. Gestão de recursos renováveis: fundamentos teóricos de um programa de pesquisas. In: VIEIRA, P. F.; WEBER, $\mathrm{J}$. (Org.). Gestão de recursos naturais renováveis e desenvolvimento. Novos desafios para a pesquisa ambiental. São Paulo: Cortez, 1997. p. 115-146.

ZANONI, M. M.; MIGUEL, L. A. Impacts des politiques de protecion de l'environment sur les pratiques pausannes (Guaraqueçaba-Brésil). Seminaire fertilité du milieu et strategies pausannes sous les tropiques humides. Montpellier, CIRAD, 1995. p. 9-20. 